\title{
EFEKTIVITAS DIMENSI INTERNAL KEPALA SEKOLAH DALAM KEPEMIMPINAN PEMBELAJARAN
}

\author{
Sri Surachmi \\ FIP Universitas PGRI Banyuwangi (e-mail:uniba.akademik@gmail.com; \\ HP: 08123482730)
}

\begin{abstract}
The Effectiveness of the Principal's Internal Dimensions in the Instructional Leadership. This study aims to investigate and analyze the effectiveness of internal dimensions related to the principal's instructional leadership in SMP Negeri 2 Glagah, Banyuwangi. This study involved 140 participants as the sample, selected using the purpose sampling technique. The data were collected using a Likert-scale questionnaire and were analyzed using the descriptive technique. The results indicated that the internal dimensions were very effective, shown by (1) the indicator of the school's mission, with a score of 516.3 and a percentage of $93.939 \%$; (2) the indicator of the instructional organization with a score of 525.5 and a percentage of $93.839 \%$; (3) the indicator of instructional practice improvement with a score of 511.0 and a percentage of $91.25 \%$; and (4) the indicator of positive school climate improvement with a score of 490.6 and a percentage of $87.611 \%$. On the whole, the mean score of internal dimensions related to instructional leadership was 510.85 with a percentage of $91.22 \%$.
\end{abstract}

Keywords: effectiveness, instructional leadership, internal dimensions

\section{PENDAHULUAN}

Kebijakan umum Departemen Pendidikan Nasional, khususnya yang berkenaan dengan SMP, diarahkan pada peningkatan mutu SMP melalui peningkatan proses pembelajaran di kelas, penyediaan buku pelajaran, pengadaan alat pelajaran, dan pelaksanaan lomba peningkatan mutu pendidikan tingkat nasional dan internasional. Namun, hasil kajian Samani (1999), menunjukkan bahwa berbagai upaya kebijakan pendidikan, terutama yang dirancang dan dikendalikan dari pusat, seperti penataran guru, pengadaan peralatan dan buku, bahkan sampai pada per- ubahan kurikulum, berdampak sangat kecilpada proses pembelajaran di kelas. Di samping itu, hasil kajian Soegiono (1998) menunjukkan bahwa sebagian besar guru kurang memiliki kemampuan dan kemauan untuk menyusun perangkat kegiatan belajar mengajar, serta menggunakannya sebagai acuan dalam menyelenggarakan kegiatan belajar mengajar di kelas. Diungkapkan pula bahwa belum semua kepala sekolah mampu mempengaruhi dan menggerakkan guru untuk merasa sadar dan bertanggungjawab bahwa perangkat kegiatan belajar mengajar merupakan kebutuhan yang wajib disusun dan di- 
gunakan secara konsisten dan tepat guna untuk mencapai tujuan pembelajaran secara efektif dan efisien.

Efektivitas kepemimpinan pembelajaran Kepala Sekolah SMP Negeri 2 Glagah, Banyuwangi sampai saat ini dapat terlaksana, tetapibelum maksimal sesuai harapan. Dikatakan demikian karena sudah memenuhi kriteria kepemimpinan pembelajaran kepala sekolah efektif, tetapi belum maksimal. Hal tersebut dapat dilihat dari gambaran dimensi-dimensi internal yang berkaitan dengan kepemimpinan pembelajaran kepala sekolah dalam meningkatkan kinerja guru yang meliputi: (1) proses sosialisasi visi dan misi sekolah di SMP Negeri 2 Glagah belum dilaksanakan secara optimal; (2) bentukbentuk penataan pembelajaran belum ditata dengan maksimal, (3) cara-cara peningkatan praktik pembelajaran belum diupayakan secara sungguh-sungguh; dan (4) cara-cara penciptaan iklim pembelajaran yang sehat di sekolah, belum maksimal. Penelitian ini mencoba mencarikan pemecahannya yang belum maksimal sehingga mendapatkan hasil yang memenuhi kriteria kepemimpinan pembelajaran yang efektif.

Berdasarkan uraian di atas, permasalahan dalam penelitian ini adalah seberapa besar dimensi-dimensi internal kepemimpinan pembelajaran kepala sekolah (proses sosialisasi visi dan misi sekolah, bentuk-bentuk penataan pembelajaran, cara-cara peningkatan praktik pembelajaran, dan cara-cara penciptaan iklim pembelajaran yang sehat di sekolah) memberikan kontribusi terhadap efektivitas kepemimpinan pembelajaran kepala sekolah?
Tujuan yang ingin dicapai dari penelitian ini adalah untuk mengungkapkan dan menganalisis efektivitas dimensi-dimensi internal yang berkaitan dengan kepemimpinan pembelajaran Kepala Sekolah SMP Negeri 2 Glagah, Banyuwangi yang meliputi deskripsi tentang proses sosialisasi visi dan misi sekolah, bentuk-bentuk penataan pembelajaran, cara-cara peningkatan praktik pembelajaran, dan deskripsi tentang cara-cara peningkatan iklim pembelajaran yang sehat di sekolah. Hasil penelitian ini diharapkan bermanfaat sebagai bahan kajian bagi usaha pengembangan kepemimpinan pembelajaran kepala sekolah secara efektif, baik di sekolah-sekolah negeri maupun swasta.

Banyak faktor yang menentukan kualitas proses hasil pembelajaran di sekolah, di antaranya adalah kualitas guru (Suryadi, 1991; Tilaar, 1998). Ditinjau dari aspek pembinaan, yang merupakan salah satu tugas kepala sekolah, beberapa studi yang dilakukan Depdikbud (1998) menunjukkan bahwa rendahnya profesionalisme guru di antaranya disebabkan karena: (1) program pembinaan tenaga kependidikan seringkali kurang sesuai dengan tujuan dan target pengembangan sekolah; (2) program pengembangan tenaga kependidikan seringkali tidak ditindaklanjuti dengan program pendukung, dalam hal ini pembinaan oleh kepala sekolah, sehingga kinerja guru yang bersangkutan kembali seperti sebelum program pembinaan dilakukan; dan (3) masih terbatasnya sumber pembelajaran yang tersedia bagi peningkatan kinerja tenaga kependidikan di sekolah. Di samping itu, faktor lain seperti rendahnya 
tingkat kesejahteraan guru, baik yang berkaitan dengan biaya hidup (living cost) maupun jaminan kesehatan dan hari tua, seringkali dipersepsi sebagai faktor yang sangat menentukan rendahnya profesionalisme guru.

Peranan kepala sekolah dalam meningkatkan profesionalisme guru sudah lama diakui sebagai salah satu faktor penting dalam organisasi sekolah, terutama tanggung jawabnya dalam meningkatkan proses pembelajaran di sekolah (Gorton \& Schneider, 1991; Hallinger \& Leithwood, 1994). Beberapa pendapatmenunjukkanbahwa sekolah efektif merupakan hasil dari tindakan kepala sekolah yang efektif (Davis \& Thomas, 1989; Sergiovanni, 1991; Mantja, 1996).

Beberapa penelitian tentang keefektifan sekolah membuktikan bahwa sekolah efektif (effective schools) mempersyaratkan kepemimpinan pembelajaran yang tangguh (strong instructional leadership) dari kepala sekolahnya, di samping karakteristik-karakteristik lainnya, seperti harapan yang tinggi pada prestasi murid, iklim sekolah yang positif bagi kegiatan belajar-mengajar, dan monitoring kemajuan belajar-mengajar yang berkelanjutan (Davis \& Thomas, 1989; DeRoche, 1985; Rossow, 1990; Smith \& Andrew, 1989; Gorton \& Schneider, 1991). Hasil penelitian tersebut mengindikasikan bahwa munculnya sekolah berprestasi yang juga sering disebut sebagai sekolah yang berhasil (successful schools), atau sekolah yang baik (good schools), tidak dapat dilepaskan dari peranan yang dimainkan kepala sekolah sebagai pemimpin pembelajaran.
Namun, kenyataan di lapangan menunjukkan bahwa peran penting kepala sekolah tersebut nampaknya belum diimbangi dengan kepemilikan kemampuan profesional yang memadai. Hasil kajian Samani (1997) di lingkungan Pendidikan Dasar dan Menengah (SMP dan SMA), dan Beeby (1980) menunjukkan bahwa pola manajemen kepala sekolah, khususnya sekolah negeri, cenderung bersifat administratif dan sekedar melaksanakan kebijakan dari atas, dan tidak risau apakah kebijakan itu sesuai atau tidak dengan tujuan dan target pengembangan sekolahnya. Dalam kondisi ini, kepala sekolah lebih tampil sebagai penatalaksana sekolah daripada sebagai pemimpin yang menakhodahi sekolah sebagai lembaga yang bermisi menjemput masa depan (Joni, 1998). Tampaknya, apa yang disinyalir oleh Osborne dan Gaebler (1997) bahwa budaya birokrasi pada umumnya hanya menjaga agar tidak menyalahi prosedur dan bukan untuk berprestasi, juga terjadi di sekolah-sekolah.

Peran penting kepala sekolah dalam membina profesionalisme guru-guru seharusnya memiliki implikasi bahwa kepala sekolah perlu mengalihkan perhatian dari sekedar melakukan pembinaan administratif menjadi pembinaan profesional dengan pusat perhatian pada peningkatan kinerja guru dalam mengelola pembelajaran. Dalam hal ini, kepala sekolah harus dapat memainkan perannya sebagai pemimpin pembelajaran (instructional leaders), yakni mengembangkan lingkungan kerja yang produktif dan memuaskan guru, serta pada akhirnya dapat meningkatkan 
hasil belajar siswa (Greenfield, 1987; Davis \& Thomas, 1989; Gorton \& Schneider, 1991).

Sebagai pemimpin pembelajaran, peranan kepala sekolah memiliki pengaruh terhadap pertumbuhan prestasi belajar siswa di antaranya melalui peningkatan kepuasan guru terhadap pelaksanaan peranan profesionalnya (Smith \& Andrew, 1989), dan melalui perbaikan iklim dan budaya sekolah, serta melalui penataan dan praktik pembelajaran (Heck, et al., 1990; Ubben \& Hughes, 1992). Dengan demikian, kepemimpinan pembelajaran kepala sekolah lebih bersifat transaksional yang di antaranya dicirikan dengan pemenuhan kebutuhan guru dan murid berdasarkan tujuan sekolah yang telah disepakati bersama.

Menurut Heck, et al. (1990) kepemimpinan pembelajaran adalah suatu multidimensional construct yang berkenaan dengan bagaimana kepala sekolah dapat mengorganisir dan mengkoordinir kehidupan kerja (the work life) di sekolah yang tidak hanya berbentuk pengalaman-pengalaman belajar dan prestasi belajar siswa, namun juga lingkungan di mana kegiatan itu dilaksanakan. Dalam hal ini, sebagai seorang pemimpin, kepala sekolah dituntut memiliki visi dan misi yang jelas, serta kemandirian dan kreativitas untuk mewujudkan visi dan misi tersebut. Kepala sekolah dituntut mampu mensinergikan potensi-potensi yang dimiliki dengan sumber-sumber yang terdapat di lingkungannya sehingga dapat menampilkan kinerja yang optimal, terutama di bidang pembelajaran. Oleh karena itu, identifikasi perilaku kepe- mimpinan pembelajaran kepala sekolah yang dikaitkan secara langsung dengan proses dan hasil pembelajaran di sekolah menjadi sangat penting dan menarik, khususnya bagi peneliti, untuk dijadikan fokus penelitian ini.

Perhatian pada konsep kepemimpinan pembelajaran (instructional leadership), sebagaimana diungkapkan oleh Smith dan Andrews (1989) berawal dari studi tentang sekolah efektif (effective schools) yang dilakukan oleh Ron Edmonds pada tahun 1979 yang menyimpulkan bahwa peranan yang dimainkan kepala sekolah, seperti interaksi kepala sekolah dengan guru-guru di sekolah, memiliki pengaruh yang kuat pada perilaku guru dan pada akhirnya pada hasil belajar siswa. Di samping itu, walaupun kepala sekolah biasanya banyak dilibatkan dalam berbagai situasi yang memerlukan kepemimpinan, namun yang lebih penting bagi seorang kepala sekolah adalah memiliki kepemimpinan bidang pembelajaran di sekolah. Dalam hal ini, peran kepemimpinan kepala sekolah dalam memperbaiki pembelajaran dan perfomansi siswa (to improve instruction and student performance) disebut kepemimpinan pembelajaran (Bradshaw, 1999).

Menurut Greenfield, (1987) kepemimpinan pembelajaran adalah tindakan yang dilakukan (kepala sekolah) dengan maksud mengembangkan lingkungan kerja yang produktif dan memuaskan bagi guru, serta pada akhirnya mampu mengembangkan kondisi belajar yang memungkinkan hasil belajar siswa meningkat. Meskipun memiliki cakupan yang sangat luas, namun secara implisit definisi ini me- 
ngandung maksud bahwa kepemimpinan pembelajaran merupakan tindakan yang mengarah pada terciptanya iklim sekolah yang mampu mendorong terjadinya peningkatan pengelolaan internal sekolah sehingga memungkinkan terselenggaranya proses pembelajaran yang optimal di sekolah.

Kepemimpinan pembelajaran kepala sekolah juga dapat diartikan sebagai tindakan kepala sekolah, baik secara langsung maupun tidak langsung, yang mengarah pada upaya peningkatan kemajuan belajar siswa. Hal ini sesuai dengan pendapat DeBevoise (1984:14-15) yang menyatakan bahwa kepemimpinan pembelajaran adalah "those actions that a principal takes, or delegates to others, to promote growth in student learning". Sementara itu, Gorton (1976), David dan Thomas (1989) mengemukakan bahwa tujuan utama kepemimpinan pembelajaran adalah memperbaiki hasil belajar siswa, walaupun tujuan yang lebih dekat adalah untuk memperbaiki kegiatan pembelajaran. Dengan demikian, dapat dikatakan bahwa kepemimpinan pembelajaran pada dasarnya bertujuan memperbaiki proses pembelajaran di sekolah, tentu saja, dalam upaya untuk meningkatkan hasil belajar siswa.

Menurut Kleine-Kracht (1993), kepemimpinan pembelajaran dapat terjadi secara langsung (direct instructional leadership) dan tidak langsung (indirect instructional leadership). Kepala sekolah bertindak sebagai direct instructional leaders bilamana kepala sekolah bekerja dengan guru-guru dan staf lainnya untuk mengembangkan proses dan hasil belajar siswa (Paterson, 1989). Tindakan kepala sekolah seperti merencanakan dan melaksanakan supervisi kunjungan kelas, atau mengobservasi guru di kelas, serta mengadakan pertemuan balikan dengan guru adalah contoh tindakan direct instructional leadership dari kepala sekolah. Sebaliknya, kepala sekolah juga dapat bertindak sebagai indirect instructional leaders dengan cara memberkan kemudahan-kemudahan (facilities) kepada guru untuk mengaktualisasikan dirinya, di antaranya dengan cara membangun kondisi-kondisi yang mendukung pelaksanaan kegiatan pembelajaran dan evaluasi hasil belajar.

Kepala sekolah dan segala sesuatu yang terkait dengan jabatannya, telah menjadi subjek dari ratusan penelitian sejak 30 tahun silam (Rossow, 1990). Beberapa penelitian, seperti penelitian Trump tahun 1950-an, studi Goldhammer tahun 1960 an, proyek penelitian Brookover tahun 1979, dan Edmon tahun 1979 menunjukkan bahwa kepala sekolah merupakan individu yang sangat penting dalam menciptakan sekolah efektif. Peranan sentral kepala sekolah tersebut telah dipandang dari berbagai sudut, yakni sebagai administrator, agen perubahan (agent of change), dan sebagai pemimpin pembelajaran (Smith \& Andrews, 1989). Dalam hal ini, Hanny (1987) menyatakan bahwa kepemimpinan pembelajaran menjadi bagian penting dari tugas seorang kepala sekolah, sebab kepala sekolah yang efektif diharapkan dapat menjadi pemimpin pembelajaran yang efektif.

Pada bagian lain, DeRoche (1989) mengidentifikasi sepuluh faktor yang berkaitan dengan aspek-aspek kepemimpinan pembelajaran kepala sekolah 
yang efektif, yaitu: (1) memberikan perhatian yang tinggi pada aspek-aspek akademik; (2) melaksanakan supervisi pengajaran; (3) mengevaluasi kinerja guru; (4) melaksanakan pengembangan staf; (5) membangun dan mendorong pengambilan keputusan kooperatif; (6) menetapkan sistem evaluasi hasil belajar siswa; (7) menetapkan standar penilaian keefektifan kurikulum; (8) menyediakan sumber-sumber pembelajaran yang diperlukan guru dan siswa; (9) menetapkan seperangkat standar keberhasilan pembelajaran; dan (10) melaksanakan fungsi sebagai manajer pembelajaran (instructional manager) yang efektif.

Akhirnya, Ubben dan Hughes (1992) mengidentifikasi beberapa perilaku kepala sekolah sebagai pemimpin pembelajaran yaitu: (1) mengkoordinir program pembelajaran; (2) memberikan perhatian yang tinggi pada prestasi belajar siswa; (3) mengevaluasi kemajuan siswa secara periodik; dan positif bagi pembelajaran; (5) membantu guru menetapkan strategi pembelajaran yang tepat; dan (6) memberi dukungan terhadap guru untuk meningkatkan kinerjanya.

Dimensi-dimensi internal kepemimpinan pembelajaran kepala sekolah yang efektif merupakan perwujudan dari perilaku kepala sekolah sebagai pemimpin pembelajaran (Heck, et al., 1990; Ubben \& Hughes, 1992). Implementasi perilaku kepemimpinan pembelajaran kepala sekolah dapat dilihat dari kemampuannya mengelola dimensi-dimensi internal sekolah sehingga guru-guru terdorong untuk meningkatkan kinerjanya. Dimensi-dimensi inter- nal sekolah tersebut meliputi: penetapan misi sekolah (defining the school's mission), penataan pembelajaran (instructional organization), peningkatan praktik pembelajaran (improving instructional practice), dan peningkatan iklim pembelajaran yang positif di sekolah (promoting positive school climate) (Hallinger, et al., 1983; Rossow, 1990; Ubben \& Hughes, 1992).

Pada dasarnya, visi dan misi sekolah merupakan rumusan tentang "sekolah ini ingin menjadi apa" (what the school can be), dan tentang "apa yang mereka inginkan untuk dicapai" (what they want to accomplish) di masa datang (Davis \& Thomas, 1989; Sinamo, 1998). Selain itu, Hallinger, et al. (1983) menegaskan bahwa misi sekolah efektif adalah improveing student achievement.

Sebagai pemimpin pembelajaran, kepala sekolah memiliki peranan penting, terutama dalam penyusunan (forming) dan pengkomunikasian (communicating) visi dan misi sekolahnya kepada pihak-pihak terkait, baik pada situasi formal maupun informal. Bagaimana visi dan misi sekolah dikembangkan, Archilles (dalam Davis \& Thomas, 1989) menyatakan bahwa visi sekolah dapat dikembangkan dengan: (1) membaca literatur tentang sekolah efektif, terutama tentang visi kepala sekolahnya; dan (2) mengunjungi sekolah efektif dan belajar tentang apa yang terjadi pada kepemimpinan yang efektif. Menurut Rutherford (Smith \& Andrews, 1989), sebagai pemimpin pembelajaran, kepala sekolah pada sekolah efektif seharusnya memiliki: (1) visi yang jelas tentang apa yang ingin dicapai sekolah; (2) kemampuan menetapkan tujuan dan 
sasaran sekolah sesuai dengan visi tersebut dan menyampaikannya kepada warga sekolah; (3) kemampuan untuk memantau kemajuan sekolah secara kontinyu sesuai dengan visi sekolah, dan (4) sikap suportif dan korektif bila ada penyimpangan pelaksanaan kegiatan yang tidak mengarah pada visi sekolah.

Menurut Rossow (1990), penataan pembelajaran (instructional organization) menunjuk pada aspek-aspek teknis dari program sekolah. Dalam hal ini, perilaku kepemimpinan pembelajaran kepala sekolah mengarah pada pengelolaan struktur kerja guru dan siswa, seperti penyusunan rancangan dan tujuan pembelajaran, pengelompokan guru dalam tim guru bidang studi, pengelompokan siswa dalam kelas, penentuan ukuran kelas (class size), penataan struktur jadwal, penetapan sistem penyediaan dan pengiriman sumber-sumber pembelajaran yang dibutuhkan guru, serta pengaturan pelaksanaan evaluasi pembelajaran yang berkelanjutan (Heck, et al.,1990; Rossow; 1990; Ubben \& Hughes, 1992).

Praktik pembelajaran (instructional practice) berkenaan dengan metode apa yang digunakan guru dan bagaimana metode tersebut digunakannya dalam mengajar di kelas (DeRoche, 1987). Kepala sekolah perlu memelihara hubungan yang akrab (close contact) dengan pelaksanaan mengajar guru di kelas. Hal ini dapat dilakukan dengan sering melakukan kunjungan kelas untuk mengobservasi guru mengajar dan mendiskusikan hasil observasi dengan guru untuk meningkatkan proses pembelajaran di kelas (Hallinger, et al., 1983;
Ubben \& Hughes, 1992; Rossow, 1990). Dengan perkataan lain, sebagai pemimpin pembelajaran, kepala sekolah lebih banyak memerankan fungsi supervisi pengajaran dalam rangka meningkatkan mutu praktek pembelajaran dan hasil belajar siswa di sekolah.

Purkey dan Smith (1982: 64) menyatakan bahwa iklim sekolah adalah $a$ structure, process, and climate of values and norms that channel staff and students in the direction of successful teaching and learning ... increasing the organizational effectiveness of a school building.

Iklim sekolah sangat diperlukan untuk meningkatkan keefektifan organisasi sekolah, terutama keefektifan kegiatan pembelajaran di kelas. Untuk membangun iklim sekolah yang positif, diperlukan perilaku-perilaku tertentu dari kepala sekolah (Ubben \& Hugnes, 1992). Pengembangan iklim belajar yang positif di sekolah memerlukan dasar struktur organisasi yang baik, dan ini dapat ditingkatkan melalui partisipasi aktif dari seluruh komunitas sekolah dan para orang tua murid (Heck, et al., 1990; Ubben \& Hughes. 1992). Iklim pembelajaran yang baik seharusnya lebih menekankan pada keyakinan bahwa semua anak dapat belajar, dan pada pengembangan struktur hadiah (reward structure) untuk mendorong aktivitas belajar siswa. Menurut Rossow (1990), iklim sekolah menunjuk pada karakter sekolah secara keseluruhan dan juga berkenaan dengan bagaimana persepsi guru dan siswa terhadap sekolahnya. Iklim sekolah juga mencakup aspek-aspek fisik dan sosial dalam suatu keseluruhan sekolah. 
Dalam kerangka berpikir teoretik kepemimpinan pembelajaran kepala sekolah, keempat dimensi internal kepemimpinan pembelajaran kepala sekolah tersebut berkaitan dengan peningkatan kinerja guru dan hasil belajar siswa di sekolah. Dengan perkataan lain, secara teoretik perilaku kepemimpinan pembelajaran kepala sekolah dalam meningkatkan kinerja guru dan hasil belajar siswa dapat diwujudkan melalui kemampuannya menetapkan visi dan misi sekolah, menata pembelajaran, meningkatkan praktik pembelajaran, dan menciptakan iklim pembelajaran yang positif di sekolah.

\section{METODE}

Sesuai dengan tujuan penelitian sebagaimana dirumuskan sebelumnya, peneliti ingin menganalisis peristiwa yang telah terjadi dan merunut ke belakang. Melalui data yang diperoleh tersebut, dapat ditemukan faktor-faktor penyebab terjadinya peristiwa. Melalui data yang diperoleh tersebut, dapat ditemukan faktor-faktor penyebab terjadinya peristiwa yang diteliti (Sugiyono, 2002:2). Oleh karena itu, rancangan penelitian yang dipakai pada penelitian ini adalah rancangan penelitian evaluatif-deskriptif dengan pendekatan ex-post facto dalam bentuk studi kasus. Dalam penelitian yang bersifat ex-post facto, penelitian berorientasi kepada perlakuan atau manipulasi variabel bebas telah terjadi sebelumnya sehingga tidak perlu diberikan perlakuan lagi, sedangkan penelitian evaluatif berorientasi pada analisis berdasarkan pendekatan evaluasi program yang berorientasi pada manajemen yaitu suatu gambaran yang menunjukkan prosedur dan proses pelaksanaan program (Sudjana dan Ibrahim, 2001: 18). Dikatakan demikian karena penggalian data dari gejala yang diteliti tidak dilakukan intervensi atau manipulasi terhadap atribut atau ciriciri yang dimiliki sebelumnya. Penelitian ini dilaksanakan di SMP Negeri 2 Glagah, Banyuwangi, dengan mengambil fokus penelitian pada efektivitas kepemimpinan pembelajaran kepala sekolah.

Menurut Sugiyono (2005:50), penelitian kualitatif tidak menggunakan populasi karena berangkat dari kasus tertentu dan hasil kajiannya tidak akan diberlakukan ke populasi, tetapi ke situasi sosial yang diteliti atau ke tempat yang memiliki kesamaan dengan situasi yang diteliti. Sampel pada penelitian ini adalah guru-guru, pegawai, komite sekolah, dan OSIS, yang merupakan narasumber atau partisipan. Menurut Azwar (2001:88), pemilihan sampel dilakukan secara non probability sampling dengan teknik quota sampling yang tujuannya mengambil sampel sebanyak jumlah tertentu yang dianggap dapat merefleksikan ciri populasi. Mereka tidak dipilih secara acak (random), melainkan dipilih berdasarkan pertimbangan-pertimbangan tertentu dan karena dianggap mengetahui efektivitas fungsi dari aspek gambaran dimensidimensi internal, serta indikator-indikatornya yang berpengaruh terhadap penciptaan sekolah efektif di SMP Negeri 2 Glagah, Banyuwangi dengan total sampel 140 partisipan (43 orang guru, 15 orang pegawai, 17 orang komite sekolah, dan 55 orang OSIS). 
Variabel yang diteliti dalam penelitian ini adalah keseluruhan aspek atau komponen kepemimpinan pembelajaran kepala sekolah yang mendukung terciptanya sekolah efektif. Variabel yang dimaksud di dalam penelitian ini merujuk kepada aspek gambaran dimensidimensi internal yang berkaitan dengan kepemimpinan pembelajaran kepala sekolah yang efektif dengan indikator: (1) proses sosialisasi visi dan misi sekolah, (2) bentuk-bentuk penataan pembelajaran; (3) cara-cara peningkatan praktek pembelajaran; dan (4) cara-cara penciptaan iklim pembelajaran yang sehat di sekolah terhadap pengelolaan pembelajaran di SMP Negeri 2 Glagah, Banyuwangi.

Dimensi-dimensi internal sekolah dalam kepemimpinan pembelajaran kepala sekolah yang dimaksudkan dalam penelitian ini adalah kepala sekolah mengaktualisasikan perilaku kepemimpinan pembelajaran pada aktivitas-aktivitas yang terkait dengan sosialisasi misi sekolah, penataan pembelajaran, peningkatan praktek pembelajaran, dan penciptaan iklim pembelajaran yang sehat di sekolah.

Metode pengumpulan data menggunakan kuesioner "langsung dan tertutup" dari partisipan. Dengan menggunakan kuesioner model Skala Likert, dimaksudkan untuk memperoleh dan mengetahui gambaran tentang besaran efektivitas aspek yang diteliti. Jenis instrumen yang digunakan untuk mengungkap efektivitas aspek kepemimpinan pembelajaran kepala sekolah, disusun dengan menggunakan alternatif jawaban yang bersifat majemuk dan terdiri atas empat pilihan jawaban, yaitu Selalu (SL) diberi skor 4, Sering (SR) diberi skor 3, Jarang (JR) diberi skor 2, dan Tidak Pernah (TP) diberi skor 1. Instrumen yang dipergunakan terlebih dahulu dilakukan uji validitas dan reliabilitas instumen.

Untuk memperoleh dan mengetahui besaran efektivitas dari aspek dan indikatornya, dilakukan dengan mencari perbandingan antara skor yang diperoleh dengan skor yang diharapkan, dikali 100\% (Depdiknas, 2002). Penghitungan skor dikerjakan dengan menggunakan program aplikasi Excel dengan menggunakan Skala empat. Menurut Riduwan (2006:89), kriteria interpretasi skor efektivitas aspek dan indikator: (1) angka 25\% - 43,75\% = Tidak Efektif (TE); (2) angka 43,76\% $62,5 \%=$ Kurang Efektif (KE); (3) angka $62,51 \%-81,25 \%=$ Efektif (EF); dan (4) angka $81,26 \%-100 \%$ = Sangat Efektif (SE).

Teknik analisis data yang dipakai dalam penelitian ini adalah analisis deskriptif. Artinya, analisis ini mengutamakan teknik induksi dan argumentasi, yaitu data diklarifikasi dan dideskripsikan sesuai dengan masalah yang dipecahkan dan sesuai dengan tujuan penelitian. Pada penelitian ini, analisis statistik deskriptif digunakan pada data yang berupa skor aspek gambaran dimensi-dimensi internal yang berkaitan dengan kepemimpinan pembelajaran kepala sekolah yang efektif dengan indikator-indikatornya, yang merupakan faktor-faktor pendukung dari terwujudnya kepemimpinan pembelajaran kepala sekolah yang efektif. 


\section{HASIL DAN PEMBAHASAN}

Aspek dimensi-dimensi internal kepemimpinan pembelajaran kepala sekolah indikatornya meliputi: (1) penetapan misi sekolah (defining the school's mission); (2) penataan pembelajaran (instructional organization); (3) peningkatan praktik pembelajaran (improving instructional practice), dan (4) peningkatan iklim pembelajaran yang positif di sekolah (promoting positive school climate).

\section{Penetapan Misi Sekolah (Defining the School's Mission)}

Indikator ini terdiri dari empat pernyataan dalam kuesioner. Pernyataan itu mengenai perilaku edukasional kepala sekolah, yang mencakup antara lain tentang: mengkomunikasikan visi dan misi sekolah, merealisasikannya ke dalam tujuan dan program sekolah, serta kebijakan-kebijakan substantif bidang pembelajaran. Hasil analisis data dalam penelitian ini menunjukkan bahwa indikator penetapan visi dan misi sekolah dari aspek internal kepemimpinan pembelajaran kepala sekolah, memiliki jumlah rata-rata skor sebesar 516.30 dan efektivitas sebesar 92,188\%, seperti disajikan pada Tabel 1. Setelah dikonsultasikan dengan Rekapitulasi Skor Efektivitas, aspek internal ini tergolong sangat efektif terhadap kepemimpinan pembelajaran kepala sekolah yang efektif di SMP Negeri 2 Glagah, Banyuwangi.

Tabel 1. Penetapan Visi dan Misi Sekolah

\begin{tabular}{cccccccccccc}
\hline No. & \multicolumn{4}{c}{ Jumlah Jawaban } & \multicolumn{1}{c}{ Jml } & \multicolumn{3}{c}{ Jumlah Skor } & & Total & Efektivitas \\
\hline Item & SL & SR & JR & TP & Resp & SL & SR & JR & TP & Skor & $(\%)$ \\
\hline 1 & 97 & 25 & 11 & 7 & 140 & 388 & 75 & 33 & 25 & 521 & 93.036 \\
2 & 87 & 40 & 4 & 9 & 140 & 348 & 120 & 12 & 40 & 520 & 92.857 \\
3 & 76 & 39 & 20 & 5 & 140 & 304 & 117 & 60 & 39 & 520 & 92.857 \\
4 & 63 & 42 & 28 & 7 & 140 & 252 & 126 & 84 & 42 & 504 & 90 \\
Jml & 323 & 146 & 63 & 28 & 560 & 1292 & 438 & 189 & 146 & 2065 & 368.75 \\
r & 80.8 & 36.5 & 15.8 & 7 & 140 & 323 & 110 & 47.3 & 36.5 & 516.3 & 92.188 \\
\hline
\end{tabular}

Tingginya partisipasi indikator penetapan visi dan misi sekolah ini menurut pengamatan peneliti antara lain disebabkan karena kepala sekolah memiliki: (1) visi yang jelas tentang apa yang ingin dicapai sekolah; (2) kemampuan menetapkan tujuan dan sasaran sekolah sesuai dengan visi tersebut dan menyampaikannya kepada warga sekolah; (3) kemampuan untuk memantau kemajuan sekolah secara kontinyu sesuai dengan visi sekolah; dan (4) sikap suportif dan korektif bila ada penyimpangan pelaksanaan kegiatan yang tidak mengarah pada visi sekolah.

Data tersebut di atas, juga menunjukkan bahwa terdapat 7,812\% (100\% $92,188 \%$ ) indikator penetapan visi dan misi sekolah yang belum memberikan dukungan sepenuhnya terhadap dimen- 
si internal kepemimpinan pembelajaran kepala sekolah. Hal itu ditunjukkan oleh keterbatasan kemampuan kepala sekolah dan warga sekolah untuk memantau kemajuan sekolah secara kontinyu sesuai dengan visi sekolah.

\section{Penataan Pembelajaran (Instructional Organization)}

Indikator ini terdiri dari delapan pernyataan dalam kuesioner. Pernyataan itu mengenai penataan pembelajaran, yang mencakup antara lain tentang: pengelolaan struktur kerja guru dan siswa, seperti penyusunan rancangan dan tujuan pembelajaran, pengelompokan guru dalam tim guru bidang studi, pengelompokan siswa dalam kelas, penentuan ukuran kelas (class size), penataan struktur jadwal, penetapan sistem penyediaan dan pengiriman sumbersumber pembelajaran yang dibutuhkan guru, serta pengaturan pelaksanaan evaluasi pembelajaran yang berkelanjutan. Data yang diperoleh dalam penelitian ini menunjukkan bahwa indikator penataan pembelajaran memiliki jum- lah rata-rata skor sebesar 525,50 dan efektivitas sebesar 93,839\% (Tabel 2). Setelah dikonsultasikan dengan Rekapitulasi Skor Efektivitas, aspek internal ini tergolong sangat efekt if terhadap kepemimpinan pembelajaran kepala sekolah.

Berdasarkan hasil pengamatan, tingginya partisipasi indikator penataan pembelajaran ini disebabkan karena: (1) kemampuan kepala sekolah mengorganisasikan kegiatan pembelajaran, melalui manajemen partisipatif dan kegiatan inovatif; (2) penetapan standar akademik yang tinggi; dan (3) kegiatan evaluasi belajar yang objektif dan berkelanjutan.

Data pada tabel 2 juga menunjukkan bahwa 6,161\% (100\% - 93,839\%) masih ada indikator penataan pembelajaran belum memberikan dukungan sepenuhnya terhadap dimensi internal kepemimpinan pembelajaran kepala sekolah. Hal itu ditunjukkan oleh keterbatasan penetapan sistem penyediaan dan penyaluran sumber-sumber pembelajaran yang dibutuhkan guru.

Tabel 2. Indikator Penataan Pembelajaran

\begin{tabular}{|c|c|c|c|c|c|c|c|c|c|c|c|}
\hline No. & \multicolumn{4}{|c|}{ Jumlah Jawaban } & Jml & \multicolumn{4}{|c|}{ Jumlah Skor } & Total & Efektivitas \\
\hline Item & SL & SR & $\mathrm{JR}$ & $\mathrm{TP}$ & Resp & SL & SR & $\mathrm{JR}$ & ТP & Skor & $(\%)$ \\
\hline 5 & 87 & 32 & 18 & 3 & 140 & 348 & 96 & 54 & 32 & 530 & 94.643 \\
\hline 6 & 94 & 26 & 11 & 9 & 140 & 376 & 78 & 52 & 9 & 515 & 91.964 \\
\hline 7 & 85 & 40 & 12 & 3 & 140 & 340 & 120 & 80 & 3 & 543 & 96.964 \\
\hline 8 & 81 & 40 & 18 & 1 & 140 & 324 & 120 & 80 & 1 & 525 & 93.75 \\
\hline 9 & 87 & 35 & 14 & 4 & 140 & 348 & 105 & 70 & 4 & 527 & 94.107 \\
\hline 10 & 91 & 27 & 22 & 0 & 140 & 364 & 81 & 54 & 0 & 499 & 89.107 \\
\hline 11 & 85 & 36 & 15 & 4 & 140 & 340 & 108 & 72 & 4 & 524 & 93.571 \\
\hline 12 & 81 & 43 & 14 & 2 & 140 & 324 & 129 & 86 & 2 & 541 & 96.607 \\
\hline $\mathrm{Jml}$ & 691 & 279 & 124 & 26 & 1120 & 2764 & 837 & 548 & 55 & 4204 & 750.71 \\
\hline $\mathrm{r}$ & 86.4 & 34.9 & 15.5 & 3.25 & 140 & 345.5 & 105 & 68.5 & 6.88 & 525.5 & 93.839 \\
\hline
\end{tabular}


Peningkatan Praktik Pembelajaran (Improving Instructional Practice)

Indikator ini terdiri dari tiga pernyataan dalam kuesioner mengenai peningkatan praktik pembelajaran yang mencakup: memelihara hubungan yang akrab (close contact) dengan pelaksanaan mengajar guru di kelas, melakukan kunjungan kelas untuk mengobservasi guru mengajar dan mendiskusikan hasil observasi dengan guru untuk meningkatkan proses pembelajaran di kelas. Data hasil penelitian menunjukkan bahwa indikator peningkatan praktik pembelajaran dari aspek internal kepemimpinan pembelajaran kepala sekolah memiliki jumlah rata-rata skor sebesar 511,00 dan efektivitas sebesar $91.25 \%$. Setelah dikonsultasikan dengan rekapitulasi skor efektivitas, aspek internal ini tergolong sangat efektif terhadap kepemimpinan pembelajaran kepala sekolah di SMP Negeri 2 Glagah, Banyuwangi.

Tingginya partisipasi indikator peningkatan praktik pembelajaran ini antara lain disebabkan karena: (1) telah adanya diagnosis pembelajaran melalui hasil observasi; (2) penyelenggaran program inservice; (3) pemanfaatan hasil belajar untuk perbaikan; (4) guru-guru telah mengoptimalkan pemberdayaan sumber pembelajaran.

Hasil analisis data menunjukkan masih terdapat 8,75\% (100\%-91.25\%) dari indikator peningkatan praktik pembelajaran yang belum memberikan dukungan sepenuhnya terhadap dimensi internal kepemimpinan pembelajaran kepala sekolah. Hal tersebut ditunjukkan oleh keterbatasan melakukan kunjungan kelas untuk mengobservasi guru mengajar dan mendiskusikan hasil observasi dengan guru untuk meningkatkan proses pembelajaran di kelas.

\section{Peningkatan Iklim Pembelajaran yang} Positif di Sekolah (Promoting Positive School Climate)

Indikator ini terdiri dari dua puluh sembilan pernyataan dalam kuesioner mengenai peningkatan iklim pembelajaran yang positif di sekolah, mencakup pengembangan iklim belajar yang positif. Data yang diperoleh dalam penelitian ini menunjukkan bahwa indikator peningkatan iklim pembelajaran dari aspek internal kepemimpinan pembelajaran kepala sekolah memiliki jumlah rata-rata skor sebesar 490,60 dan efektivitas sebesar $87.611 \%$. Setelah dikonsultasikan dengan rekapitulasi skor efektivitas, aspek internal ini tergolong sangat efektif. Menurut hasil pengamatan, tingginya partisipasi indikator ini antara lain disebabkan karena: (1) terciptanya mekanimse kerja yang mampu mendorong terjadinya diskusi dengan guru dan siswa tentang pembelajaran; dan (2) terciptanya sistem penghargaan terhadap prestasi guru dan siswa sehingga terjadi iklim yang sehat.

Data tersebut di atas juga menunjukkan bahwa 12,389\% (100\% - 87,611\%) masih ada indikator peningkatan iklim pembelajaran belum memberikan dukungan sepenuhnya terhadap dimensi internal kepemimpinan pembelajaran kepala sekolah. Hal itu ditunjukkan oleh keterbatasan pada pengembangan struktur hadiah (reward structure) untuk mendorong aktivitas belajar siswa. 
Aspek Dimensi Internal Kepemimpinan Pembelajaran Kepala Sekolah

Data hasil penelitian ini menunjukkan bahwa keempat indikator dari aspek dimensi internal kepemimpinan pembelajaran kepala sekolah (Tabel 3), memiliki jumlah rata-rata skor sebesar
510.85 dan efektivitas sebesar 91.222\%. Setelah dikonsultasikan dengan rekapitulasi skor efektivitas, aspek internal ini tergolong sangat efektif terhadap kepemimpinan pembelajaran Kepala Sekolah efektif di SMP Negeri 2 Glagah, Banyuwangi.

Tabel 3. Aspek Dimensi Internal Kepemimpinan Pembelajaran Kepala Sekolah

\begin{tabular}{clcc}
\hline No & \multicolumn{1}{c}{ Indikator Subkomponen } & Jumlah Skor & Efektivitas (\%) \\
\hline 1 & Penetapan Visi dan Misi sekolah & 516.3 & 92.188 \\
2 & Penataan pembelajaran & 525.5 & 93.839 \\
3 & Peningkatan praktik pembelajaran & 511,0 & 91.25 \\
4 & Peningkatan iklim pembelajaran & 490.6 & 87.611 \\
& Jumlah & 2043.4 & 364.888 \\
& Rata-rata & 510.85 & 91.222 \\
\hline
\end{tabular}

Data tersebut juga menunjukkan bahwa $8,778 \%(100 \%-91,222 \%)$ masih terdapat aspek dimensi internal kepemimpinan pembelajaran kepala sekolah yang belum memberikan dukungan sepenuhnya terhadap kepemimpinan pembelajaran kepala sekolah, baik dari indikator penetapan misi sekolah, penataan pembelajaran, praktik pembelajaran, maupun dari iklim pembelajaran. Hal itu ditunjukkan oleh keterbatasan kemampuan kepala sekolah dan warga sekolah untuk memantau kemajuan sekolah secara kontinyu sesuai dengan visi sekolah; keterbatasan penetapan sistem penyediaan dan penyaluran sumber-sumber pembelajaran yang dibutuhkan guru; keterbatasan melakukan kunjungan kelas untuk mengobservasi guru mengajar dan mendiskusikan hasil observasi dengan guru untuk meningkatkan proses pembelajaran di kelas; dan keterbatasan padapengembangan struk- tur hadiah (reward structure) untuk mendorong aktivitas belajar siswa.

\section{PENUTUP}

\section{Kesimpulan}

Berdasarkan hasil analisis dan pembahasan di atas, dapat disimpulkan beberapa hal sebagai berikut.

- Indikator penetapan visi dan misi sekolah memiliki jumlah skor sebesar 516,3 dengan kategori efektivitas sangat efektif, dan persentase efektivitas sebesar $92.188 \%$. Masih terdapat $7,812 \%$ indikator penetapan visi dan misi sekolah yang belum memberikan dukungan sepenuhnya terhadap dimensi internal kepemimpinan pembelajaran kepala sekolah yang disebabkan oleh keterbatasan kemampuan kepala sekolah dan warga sekolah untuk memantau kemajuan sekolah secara kontinyu sesuai dengan visi sekolah. 
- Jumlah skor untuk indikator penataan pembelajaran sebesar 525,5 dengan kategori efektivitas sangat efektif, dan persentase efektivitas sebesar $93,839 \%$. Terdapat $6,161 \%$ dari indikator ini yang belum memberikan dukungan sepenuhnya terhadap dimensi internal kepemimpinan pembelajaran kepala sekolah. Hal tersebut ditunjukkan oleh keterbatasan penetapan sistem penyediaan dan penyaluran sumber-sumber pembelajaran yang dibutuhkan guru.

- Indikator peningkatan praktik pembelajaran dengan jumlah skor 511,00 termasuk dalam kategori efektivitas sangat efektif, dan persentase efektivitas sebesar $91.25 \%$. Masih terdapat $8,75 \%$ dari indikator peningkatan praktik pembelajaran yang belum memberikan dukungan sepenuhnya terhadap dimensi internal kepemimpinan pembelajaran kepala sekolah. Hal tersebut disebabkan oleh keterbatasan melakukan kunjungan kelas untuk mengobservasi guru mengajar dan mendiskusikan hasil observasi dengan guru untuk meningkatkan proses pembelajaran di kelas.

- Indikator peningkatan iklim pembelajaran yang positif di sekolah memiliki jumlah skor 490.6 dengan kategori efektivitas sangat efektif, dan persentase efektivitas sebesar $87.61 \%$. Masih terdapat sebesar $12,389 \%$ dari indikator peningkatan iklim pembelajaran yang belum memberikan dukungan sepenuhnya terhadap dimensi internal kepemimpinan pembelajaran kepala sekolah. Hal tersebut ditunjukkan oleh keterbatasan pada pengembangan struktur hadiah (re- ward structure) untuk mendorong aktivitas belajar siswa.

- Keempat indikator dari aspek dimensi internal kepemimpinan pembelajaran kepala sekolah memiliki jumlah rata-rata skor sebesar 510.85 dan efektivitas sebesar $91.222 \%$, yang tergolong sangat efektif terhadap kepemimpinan pembelajaran kepala sekolah efektif di SMP Negeri 2 Glagah, Banyuwangi. Secara keseluruhan masih terdapat $8,778 \%$ dari aspek dimensi internal tersebut yang belum memberikan dukungan sepenuhnya terhadap kepemimpinan pembelajaran kepala sekolah, baik dari indikator penetapan misi sekolah, penataan pembelajaran, praktek pembelajaran, maupun dari indikator iklim pembelajaran.

\section{Saran}

Berdasarkan hasil penelitian yang telah disimpulkan di atas, saran yang perlu dipertimbangkan adalah (1) mengefektifkan pelaksanaan supervisi kunjungan kelas sebagai sarana pembinaan kemampuan profesional, sosial, dan personal guru dengan lebih berorientasi pada kebutuhan guru; (2) meningkatkan sistem reward kepada guru, pegawai, dan siswa secara berkeadilan sesuai dengan kinerja masing-masing karena sistem insentif (reward) sangat berpengaruh terhadap kinerja guru, pegawai, dan siswa sehingga hal ini disarankan untuk tetap direkomendasikan; dan (3) bagi peneliti berikutnya, agar dilakukan penelitian lanjut yang dapat mengungkap lebih jauh tentang kepemimpinan pembelajaran kepala se- 
kolah dengan menggunakan pendekatan penelitian yang berbeda.

\section{UCAPAN TERIMA KASIH}

Terima kasih saya ucapkan kepada Redaktur Jurnal Cakrawala Pendidikan yang telah memberi input untuk penyempuraan artikel ini.

\section{DAFTAR PUSTAKA}

Azwar, Saifuddin. 2001. Metode Penelitian. Yogyakarta: Pustaka Pelajar.

Beeby, C. E. 1980. Pendidikan di Indonesia: Penilaian dan Pedoman Perencanaan. Terjemahan oleh BP3K dan YIIS. Jakarta: LP3ES.

Bradshaw, L. K. 1999. “Opportunities for Instructional Leadership at Rolling Ridge Middle School". The Journal Of Cases in Educational Leadership, Volume 2, Number 3, (http://www.ucea.ore/cases N2Iss3/rolliniz.htmt.

Davis, G. A \& Thomas, M. A. 1989. Effective School and Effective Teachers. Boston: Allyn and Bacon Inc.

DeRoche, E. F. 1985. An Administrator's Guide for Evaluating Programs and Personnel: An Effective Schools Approach. Boston: Allyn and Bacon Inc.

Gorton, R. A. 1976. School Administration: Challenge and Opportunity for Leadership. Dubuque, Iowa: Wm C Brown Company Publisher.

Gorton, R. A., \& Schneider, G. T. 1991. Schools-based Leadership: Challeng- es and opportunities. Dubuque, Iowa: Wim C. Brown Company Publisher.

Greenfield,W. D. 1987. Instructional Leadership: Concepts, Issue, and Controversies. Boston: Allyn and Bacon.

Hallinger, P., Murphy, I., Well, M., Mesa, R. F. \& Mitman, A. 1983. "Identifying the Specific Practices and Behaviors for Principals". NASSI Bulletin, May:83-91.

Hallinger, P. \& Leithwood, K. 1994. "Introduction: Exploring the Impact of Principal Leadership. School Effectiveness and School Improvement". An International Journal of Research, Policy, and Practice. September, 5(3): 206218.

Heck, R. H.; Larsen, T. J. \& Marcoulides, G. A. 1990. “Instructional Leadership and School Achievement: Validation of a Causal Model". Educational Administration Quarlerly; 26(2):94-125.

Joni, T. R. 1998. “Mereka Masa Depan, Sekarang: Tantangan bagi Pendidikan dalam Menyongsong Abad Informasi". Ceramah $1 l$ miah disampaikan dalam Upacara Dies Natalis XXXV, Lustrum VII; IKIP MALANG, Malang, 18 Oktober.

Mantja, W. 1996. "Kompetensi Kekepalasekolahan: Landasan. Peran, dan Tanggugngjawabnya". Jur- 
nal Filsafat, Teori, dan Praktik Kependidikan, 23 (1): 56-69.

Osborn, D. \& Gaebler, T. 1997. Reinventing Government: How the Entrepreneurial Spirit is Transforming the Public Sector. Terjemahan oleh Abdul Rosjid. Jakarta: PT Pustaka Binaman Pressindo.

Riduwan. 2006. Skala Pengukuran Variabel-variabel Penelitian. Bandung: Alfabeta.

Rossow, L.F. 1990. The Principals: Dimensions in Instructional Leaderships. Boston: Allyn and Bacon.

Samani, M. 1999. "School-Based Management: Strategi Pemberdayaan Sekolah dalam Kerangka Desentralisasi Pendidikan Menuju Pendidikan yang Berkualitas". Makalah disajikan dalam Seminar Nasional Formula Manajemen Pendidikan dalam Kerangka Otonomi Daerah di Malang: 23 Agustus.

Sergiovanni, T. J. 1991. The Principalship: A Reflective Practice Perspective. Boston: Allyn and Bacon.

Smith W. F. \& Andrews, R. L. 1989. Instructional Leadership: How Principals Make a Difference. Washington, DC: ASCD Publications.

Soegiono. 1997. "Perangkat Kegiatan Belajar Mengajar dan Upaya Kepala Sekolah agar Setiap
Guru Menyiapkan Perangkat Kegiatan Belajar Mengajar (KB)", Makalah disajikan dalam Rapat Kerja Kepala SMP-SMU Negeri dan Swasta se Jawa Timur Tahun Pelajaran 1997/ 1998. Batu, Malang: Juli 1997.

Sudjana \& Ibrahim. 2001. Penelitian dan Penilaian Pendidikan. Bandung: Sinar Baru Algensindo.

Sugiyono. 2002. Metode Penelitian Administrasi. Bandung: Alfabeta.

Sugiyono. 2005. Statistika untuk Penelitian Bandung: Alfabeta.

Suryadi, A. 1991. Indikator Mutu dan Efisiensi Pendidikan Sekolah Dasar di Indonesia. Jakarta: Balitbang Depdikbud.

Tilaar, H.A.R. 1998. Manajemen Pendidikan Nasional. Bandung: Penerbit PT Remaja Rosdakarya.

Tilaar, H.A.R. 1991. "Regional Development, Qualily of Regional University and Secondary School Preparation in Indonesia". Makalah disampaikan pada Conference on Improving Quality in Higher Education: Indonesia as a Case. University of California. Berkeley. April 1-3.

Ubben. G.C. \& Hughes, L.W. 1992. The Principal: Creative leadership for effective school. Boston: Allyn and Bacon. 